\title{
HEMANGIOMA - RELATO DE CASO
}

Talita Izabela Caliman RODRIGUES, Larissa FONDAZZI, Priscila Flores ARANTES, Eduardo MORESCHI, Vanessa Cristina VELTRINI

O hemangioma é um tumor ou hamartoma benigno, caracterizado pela proliferação ou malformação de vasos sangüíneos. É comum no recém-nascido e na criança, porém pode haver casos em adultos. Sua localização mais comum é a região de cabeça e pescoço, tendo preferência pelo sexo feminino. Apresenta coloração que varia do vermelho ao roxo e tamanho estável, que pode regredir com o passar dos anos. A lesão inicia-se como uma área plana, que rapidamente aumenta, produzindo uma massa elevada. Paciente do gênero feminino, 7 anos, cor branca, compareceu ao Projeto de Lesões Bucais do CESUMAR por meio de encaminhamento odontopediátrico. Ao exame físico intrabucal, verificou-se a presença de mancha arroxeada, bem delimitada, em região ântero-inferior de gengiva. Foi realizado tratamento esclerosante, com aplicação de oleato de etanolamina, divididas em 2 sessões quinzenais, com sucesso. A involução do hemangioma pode ser espontânea na primeira infância. Mediante persistência, a involução é improvável, sendo necessário o tratamento definitivo.

Palavras-chave: Hemangioma; Hamartoma; Vasos sanguíneos. 